\title{
Treatment of Advanced Non Small Cell Lung Cancer (NSCLC): A Clinical Review
}

\author{
Sameer Singhal ${ }^{1}$, Jai Kishan ${ }^{2}$, Monica Singh ${ }^{3}$, Parvinder Singh ${ }^{4}$ \\ ${ }^{1}$ Professor, Department of Respiratory Medicine, ${ }^{2} \mathrm{HOD}$, Department of Respiratory Medicine, ${ }^{3}$ Junior Resident, Department \\ of Respiratory Medicine, ${ }^{4}$ Senior Resident, Department of Respiratory Medicine, M.M Institute of Medical Sciences and \\ Research, Mullana, Ambala, Haryana, India
}

Corresponding author: Dr. Monica Singh, Room No. 304, Hostel 9, MM University, Mullana, Ambala, Haryana 133203, India

DOI: http://dx.doi.org/10.21276/ijcmsr.2019.4.2.33

How to cite this article: Sameer Singhal, Jai Kishan, Monica Singh, Parvinder Singh. Treatment of advanced non small cell lung cancer (NSCLC): a clinical review. International Journal of Contemporary Medicine Surgery and Radiology. 2019;4(2):B150-B154.

\section{A B S T R A C T}

Carcinoma of lung keeps on being the main source of malignancy-related passing's all around the globe significant endeavors have been made in the treatment of advanced non-small-cell lung cancer (NSCLC) with chemotherapy. A few new specialists and new mixes of chemotherapy are accessible. The author reviews clinical trials investigating chemotherapeutic agents for advanced stage NSCLC in chemotherapy-naive patients, in patients who present with reversion or progressive disease, and in aged patients. Various clinical investigations express improvement in overall quality of life with chemotherapy treatment of advanced NSCLC. Better choices are accessible for patients who have inversion after first-line chemotherapy, and treatment of elderly patients with chemotherapy has exhibited an advantage in survival and better quality of life. Regardless of advancement with more up to date modalities for the treatment of advanced stage small cell lung carcinoma, just $14 \%$ of patients with the infection are alive at 5 years after starting determination. Early discovery should further upgrade the clinical estimation of this blend of chemotherapy and new modalities are required.

Keywords: Non Small Cell Lung Cancer, Carcinoma, Lungs

\section{INTRODUCTION}

In the beginning of the century, lung cancer was considered to be rare. ${ }^{1}$ Since, 1985 lung cancer is the most commonly diagnosed cancer annually and it has reached epidemic proportions.1In developed countries lung cancer is the leading cause of death and is rising at alarming pace in developing countries. ${ }^{2}$ In India, approximately 63,000 new lung cancer cases are reported each year. ${ }^{3}$ Histologically lung cancer is alienated into two main types as non-small cell lung cancer (NSCLC) and small cell lung cancer. Of the three main types of non-small cell lung cancer (NSCLC), the most frequent type is adenocarcinoma. Adenocarcinoma consist of $38.5 \%$ of all lung cancer, squamous cell carcinoma consist of $20 \%$ and large cell carcinoma accounts for $2.9 \% .{ }^{4}$ Incidence of adenocarcinoma has increased in last few decades and has replaced squamous cell carcinoma as the most common type of Non-Small Cell Carcinoma. ${ }^{5}$

\section{Risk Factors}

Tobacco smoking is the most imperative risk factor for lung cancer, more than $80 \%$ or 1 in 9 smokers develops lung cancer. ${ }^{6}$ The cumulative risk of lung cancer in lifelong heavy smokers is $30 \%$ and in non-smoker it is less than $1 \%{ }^{7,8}$ Lung cancer risk is proportional to number of cigarettes consumption, the age of onset of smoking the degree of inhalation nicotine and tar content of cigarette and use of un-filter cigarettes, genetic predisposition and individual susceptibility is also a factor in carcinogenesis. $^{9}$

In India patients with history of active tobacco smoking was found in $87 \%$ of males and $85 \%$ of females. Passive tobacco exposure was found in 3\%. The percentage of tobacco-related products smoked in India are beedi (28.4 - 79\%), cigarettes (9.0 - 53.7), hooka (3.4 - 77.3), and mixed (7.5 - 13.6). ${ }^{10}$

The relative risk for the development of lung cancer is 2.64 among beedi and 2.23 for cigarette smokers with overall relative risk (RR) of $2.45 .{ }^{11}$ Beedi is more carcinogenic and this has been shown by other studies also. ${ }^{12,13}$ In a study among lung cancer patients by Gupta et al.89\% of men and 33\% of women were ever smokers as compared to respectively 60 per cent of men and 20 per cent of women among controls. ${ }^{14}$ The Odds Ratio (OR) for ever-smoking was 5.0 (CI 3.11 8.04) among men and 2.47 (CI 0.79 - 7.75) among women. Smoking of beedi and hooka as well as cigarettes had similar ORs for cumulative consumption. ${ }^{15}$

Other realized noteworthy hazard factors in the pathogenesis of lung disease incorporate presentation to radon gas, asbestos, and air contamination, just as hereditary factors. ${ }^{16}$ One of the key variables starting the pathogenesis of lung malignant growth is through a direct introduction to responsive oxygen species (ROS) and by means of enactment of polymorphonuclear neutrophils. ${ }^{17}$ This prompts changes in cell-flagging and transformations, and at last to carcinogenesis. 


\section{Treatment}

Around $40 \%$ of patients with NSCLC present at a propelled stage, incorporating patients with metastatic illness and those with privately propelled sickness with harmful pleural or pericardial emanation. Treatment alternatives for these subgroups are picked dependent on patient status (PS) since it is a significant determinant of outcome. ${ }^{18}$

Combination chemotherapy is viewed as the standard of consideration for patients with advanced NSCLC and a PS score of 0 or $1 .^{19}$ Both platinum-based two-medicate regimens and non-platinum mixes have been demonstrated to be effective in the primary line treatment of cutting edge NSCLC. ${ }^{20-24}$

\section{Platinum-Based Regimens}

The advantages of platinum-based blend chemotherapy over best steady consideration (BSC) as first-line treatment for patients with cutting edge NSCLC were first revealed in a randomized clinical preliminary distributed in 1988.25

Additional proof for the viability of platinum-based chemotherapy was given by a meta-investigation of all accessible randomized clinical trials. ${ }^{26}$ The examination showed that cisplatin-based chemotherapy was related with a $10 \%$ more noteworthy 1 -year survival rate (danger proportion, 0.73). This prompted the assessment of a few platinum-based mixes for the primary line treatment of cutting edge NSCLC.

In view of the promising effects of single agent, newer agents, for example, the taxanes, gemcitabine, and vinorelbine have been joined with platinum mixes. A few randomized clinical preliminaries have been led to assess cisplatin as monotherapy or in the mix with a taxane, gemcitabine, or vinorelbine..$^{27-29}$ The two-tranquilize mixes were demonstrated to have prevalent adequacy, however to the detriment of included lethality. These examinations gave additional proof in help of the utilization of cisplatin-based blends for the principal line treatment of NSCLC.

\section{Comparison of Platinum-Based Combinations}

A four-arm randomized stage III investigation was led to look at the adequacy and poisonous quality profile of cisplatin in addition to gemcitabine, cisplatin in addition to docetaxel, and carboplatin in addition to paclitaxel, with a reference routine of cisplatin in addition to paclitaxel..$^{20}$ There was no distinction accordingly rate, middle survival time, or 1-year survival rate among the four regimens. Be that as it may, cisplatin in addition to gemcitabine conferred a more drawn out time to move.

The adequacy of gemcitabine as a first-line treatment was at first settled in two randomized preliminaries. The mix of cisplatin in addition to gemcitabine was related to higher survival and reaction rates than seen among 522 patients enduring progressed NSCLC with cisplatin monotherapy in stage III. ${ }^{28}$

In another randomized examination, cisplatin in addition to gemcitabine was contrasted and cisplatin in addition to etoposide as first-line therapy. ${ }^{30}$ Response rate, the essential endpoint, was higher with cisplatin in addition to gemcitabine, and there was additionally a pattern toward longer survival.
Docetaxel, a semisynthetic taxane, has likewise been demonstrated to be useful in the mix with a platinum compound. The routine of cisplatin in addition to docetaxel was contrasted and cisplatin in addition to vinorelbine and carboplatin in addition to docetaxel in a randomized stage III study. ${ }^{31}$ The middle and 2-year survival rates were unrivaled for cisplatin in addition to docetaxel, while the carboplatin in addition to docetaxel routine had adequacy like that of cisplatin in addition to vinorelbine.

In Japan, irinotecan has been widely assessed in blend with cisplatin for the treatment of cutting edge NSCLC. ${ }^{32,33}$ The mix was contrasted and carboplatin in addition to paclitaxel, cisplatin in addition to vinorelbine, and cisplatin in addition to gemcitabine in a four-arm, randomized clinical trial. ${ }^{34}$ The examination showed tantamount efficacies among the four regimens, and they were all very much endured.

Since a few chemotherapy regimens have comparable degrees of viability in cutting edge NSCLC, Efforts to individualize treatment dependent on sub-atomic markers in the tumor that foresee protection from explicit chemotherapeutic specialists are in progress. Extraction fix cross-supplementing one (ERCC1) quality over expression has been connected to protection from platinum. ${ }^{35} \mathrm{~A}$ randomized report allocated patients to medications dependent on ERCC1 mRNA levels in the tumor tissue at baseline. ${ }^{36}$ Patients with low ERCC1 mRNA levels were treated with cisplatin in addition to docetaxel, while those with abnormal states were treated with gemcitabine in addition to docetaxel. Reaction rates with cisplatin in addition to docetaxel were higher in patients with low ERCC1 articulation.

In an investigation, overexpression of the ribonucleotide reductase M1 (RRM1) quality has been connected to protection from gemcitabine therapy. ${ }^{37} \mathrm{~A}$ randomized stage II clinical preliminary exhibited the possibility of choosing treatment dependent on RRM1 articulation and announced high reaction rates with such a pharmacogenomic treatment choice. In light of these outcomes, a corroborative stage III examination is in advancement. Such epic and individualized systems will prompt further enhancement treatment soon.

\section{Carboplatin v/s Cisplatin}

A few examinations have been led to contrasting carboplatinbased regimens and cisplatin-based mixes in the primary line treatment of cutting edge NSCLC..$^{20,31,38}$ While a few investigations have proposed a slightly preferred position to cisplatin-based regimens, it is vague whether this offsets higher level of lethality found.

A meta-examination of studies contrasting cisplatin-and carboplatin-based regimens exhibited a marginally longer survival time for regimens that included cisplatin with a fresher agent. ${ }^{39}$ This perception was affirmed in another metainvestigation that utilized individual patient information to look at the adequacy of cisplatin-based regimens with that of carboplatin-based regimens for cutting edge NSCLC. ${ }^{40}$

Generally speaking, there was a marginally higher reaction rate with cisplatin-based regimens. In spite of the fact that there was no noteworthy survival distinction, thinks about that utilized a third-age specialist (gemcitabine or a taxane) in blend with cisplatin yielded a slightly preferred position over carboplatin-based regimens. 


\section{Platinum v/s Non-platinum Regimens}

The utilization of non-platinum regimens has been broadly explored with the end goal of improving the restorative file of chemotherapy for patients with cutting edge NSCLC. The upside of barring platinum mixes is that they are related to extensive poisonous quality.

Randomized preliminaries that have legitimately contrasted platinum-based regimens and non-platinum mixes have exhibited practically identical results..$^{23,24}$ An ongoing randomized examination contrasted carboplatin in addition to paclitaxel and carboplatin in addition to gemcitabine and the non-platinum routine of gemcitabine in addition to paclitaxel for NSCLC. ${ }^{24}$ All three regimens showed similar reaction rates and middle survival times. In spite of the fact that the poisonous quality profiles were diverse in each arm, there was no unmistakable bit of leeway to the non-platinum routine. The perceptions were affirmed by an ongoing meta-investigation of all examinations contrasting platinum-based regimens and non-platinum mixes, which exhibited practically identical 1 -year survival rates. ${ }^{41}$ Though the reaction rate was somewhat higher with platinum-based regimens, so was the poisonous quality. In view of this, non-platinum regimens are a sensible decision for firstline treatment of NSCLC and furthermore speak to an elective choice for patients who can't endure platinum-based regimens.

\section{Strategies to Improve the Efficacy}

Late endeavors have concentrated on the expansion of a subatomic focused on an operator to standard platinum-based blend regimens. The EGFR inhibitors have been the most widely considered in blend with chemotherapy. In spite of promising preclinical information in help of the blend regimens, stage III investigations neglected to show a survival bit of leeway related with the expansion of an EGFR tyrosine kinase inhibitor (TKI) to foundational chemotherapy. ${ }^{42-44}$ Monoclonal antibodies against EGFR, which have exhibited charming action in blend with chemotherapy in stage II studies $^{45,46}$, are currently experiencing stage III assessment and significance of contemplating tolerant choice techniques to distinguish atomic/clinical parameters that foresee advantage from the focused on specialist being assessed.

All the more as of late, bevacizumab, a monoclonal counteracting agent against vascular endothelial development factor, was shown to prompt longer survival when controlled in mix with chemotherapy. ${ }^{47}$ The significant stage III investigation (ECOG 4599) randomized patients with non-squamous NSCLC to treatment with carboplatin in addition to paclitaxel alone or in blend with bevacizumab. Patients with squamous cell histology, real hemoptysis, cerebrum metastasis, or uncontrolled hypertension and those on helpful dosages of anticoagulation were prohibited on account of concerns in regards to the uplifted danger of seeping with bevacizumab. Following six cycles of treatment, patients in the trial arm with a reaction or stable infection were given support monotherapy with bevacizumab until sickness movement or unsuitable harmfulness. There were higher occurrences of neutropenia, hypertension, discharge, proteinuria, and treatment-related passings with the three- sedate routine. Notwithstanding this, there was a more extended generally speaking survival time (12.3 months versus 10.3 months) and a higher reaction rate (35\% versus $15 \%$ ) with the expansion of bevacizumab to carboplatin in addition to paclitaxel.

\section{Maintenance Therapy}

Up to this point, there has been no demonstrated job for upkeep treatment on the grounds that randomized clinical preliminaries have neglected to show any survival advantage for the proceeded with organization of fundamental chemotherapy past three to six cycles. ${ }^{48-51}$ However, the accessible writing has a few confinements that challenge the prohibition of support treatment in NSCLC.

\section{CONCLUSION}

While advanced lung malignancy keeps on being a deadly sickness, advance in the treatment with chemotherapy in the most recent decade has enabled more patients to live more and with better personal satisfaction. The subsets of patients with dynamic sickness after chemotherapy treatment and matured patients with NSCLC advantage from select chemotherapy regimens while; endeavors to advance more up to date treatment routines, smoking suspension and lung malignant growth screening ought to remain a high need.

\section{REFERENCES}

1. Nath V, Grewal K S. Cancer in India. Ind J Med Res 1935;23(1):149-90.

2. KhuriFr, HerbstRs, Fossells FV. Emerging therapies in nonsmall-cell lung cancer. Ann Oncol2001;12 (3):73944.

3. Ferlay J, Shin HR, Bray F, Forman D, Mathers C, Parkin DM. Estimates of worldwide burden of cancer in 2008: GLOBOCAN 2008. Int J Cancer 2010;127 (5):2893-917.

4. Cancer of lung and Bronchus (invasive). In: institute NC, ed:SEER cancer statistics review 1975-2008;2011.

5. Herbst RS, Heymach JV, LippmanSM,Lung Cancer. N Engl J Med 2008:359 (13);1367-80.

6. Jemal A, Ward E, Hao Y, Tparkin DM, Bray F hun M. trends in the leading causes of death in united states, 1970 - 2002. JAMA. 2005;294(10);1255-59.

7. Mattson ME,Pollack ES, Lopez, Cullen JW. What are the odds that smoking will kill you? Am J Public health. 1987;77(4):425-31.

8. Parkin DM, Pisani P, Lopez AD, masuyer E. At least 1 in 7 cases of cancer is caused by smoking. Global estimates for 1985. Int J Cancer. 1994;59(4): 494-504.

9. Parkin DM, BreyF,Ferley J, Pisani P. Global center statistics 200. CA cancer J Clin. 2005;55(2):74-108.

10. Jindal SK, Behera D. Clinical spectrum of primary lung cancer review of Chandigarh experience of 10 years. Lung India 990;8 (1):94-98.

11. Notani P, Sanghavi LD. A retrospective study of lung cancer inBombay. Br J Cancer 1974;29 (6):477-82.

12. Jussawala DJ, Jain DK. Lung cancer in greater Bombay correlationwith religion andsmokin habits. Br J Cancer 1979; 40 (3):437-48.

13. Pakhale SS, Jayant A, Binde SV. Methods of reduction of harmfulconstituent in bidi smoke. Indian J Cest Dis 
and all Sci 1985;27 (4):148-52.

14. Gupta D, Boffetta P, Gaborieau V, Jindal SK. Risk factors of lungcancer in Chandigarh, India. Indian J Med Res 2001;113 (6):142-50.

15. Nafae A, MisraSp, Dhar SN and Shah SNA. Bronchogenic carcinomain Kashmir Valley. Ind J Chest Dis 1973;15 (1):285-95.

16. Pass HI, Carbone DP, Johnson DH, Minna JD, Scagliotti GV, Turrisi AT3. Principles and practice of lung cancer the official reference text of the international association for the study of lung cancer (IASLC). Fourth ed. LWW 2010. 1040 p.

17. Federico A, Morgillo F, Tuccillo C, Ciardiello F, Loguercio C. Chronic inflammation and oxidative stress in human carcinogenesis. Int J Cancer 2007; 11 (5):2381-86.

18. Albain KS, Crowley JJ, LeBlanc $M$ et al. Survival determinants in extensive-stage non-small-cell lung cancer: The Southwest Oncology Group experience. J ClinOncol 1991;9 (6):1618-26.

19. Ramalingam S, Belani CP. State-of-the-art chemotherapy for advanced non-small cell lung cancer. SeminOncol 2004;31(suppl 1):68-74.

20. Schiller JH, Harrington D, Belani CP et al. Comparison of four chemotherapy regimens for advanced non-smallcell lung cancer. N Engl J Med 2002;346 (5):92-98.

21. Kelly K, Crowley J, Bunn PA Jr et al. Randomized phase III trial of paclitaxel plus carboplatin versus vinorelbine plus cisplatin in the treatment of patients with advanced non-small-cell lung cancer: A Southwest Oncology Group trial. J ClinOncol 2001;19 (2):3210-18.

22. Smit EF, van Meerbeeck JP, Lianes $P$ et al. Three-arm randomized study of two cisplatin-based regimens and paclitaxel plus gemcitabine in advanced non-smallcell lung cancer: A phase III trial of the European Organization for Research and Treatment of Cancer Lung Cancer Group-EORTC 08975. J ClinOncol 2003;21 (1):3909-17.

23. Georgoulias V, Papadakis E, Alexopoulos A et al. Platinum-based and non-platinum-based chemotherapy in advanced non-small-cell lung cancer: A randomisedmulticentre trial. Lancet 2001;357 (4):1478-84.

24. Treat J, Belani CP, Edelman M et al. A randomized phase III trial of gemcitabine in combination with carboplatin or paclitaxel versus paclitaxel plus carboplatin in advanced (stage IIIb, IV) non-small cell lung cancer: Update of the Alpha Oncology Trial (A199002L). J ClinOncol 2005;23(16 suppl):627s.

25. Rapp E, Pater JL, WillanA et al. Chemotherapy can prolong survival in patients with advanced non-smallcell lung cancer-report of a Canadian multicenter randomized trial. J ClinOncol 1988;6 (1):633-41.

26. Non-Small Cell Lung Cancer Collaborative Group. Chemotherapy in nonsmall cell lung cancer: A metaanalysis using updated data on individual patients from 52 randomised clinical trials. BMJ 1995;311 (5):899909.

27. Wozniak AJ, Crowley JJ, Balcerzak SP et al. Randomized trial comparing cisplatin with cisplatin plus vinorelbine in the treatment of advanced nonsmall-cell lung cancer:
A Southwest Oncology Group study. J ClinOncol 1998;16 (1):2459-65.

28. Sandler AB, Nemunaitis J, Denham C et al. Phase III trial of gemcitabine plus cisplatin versus cisplatin alone in patients with locally advanced or metastatic nonsmall-cell lung cancer. J ClinOncol 2000;18 (3):122-30.

29. Von Pawel J, Von Roemeling R, Gatzemeier U et al. Tirapazamine plus cisplatin versus cisplatin in advanced non-small-cell lung cancer: A report of the international CATAPULT I study group. Cisplatin and tirapazamine in subjects with advanced previously untreated nonsmall-cell lung tumors. J ClinOncol 2000;18 (1):135159.

30. Cardenal F, Lopez-Cabrerizo MP, Anton A et al. Randomized phase III study of gemcitabine-cisplatin versus etoposide-cisplatin in the treatment of locally advanced or metastatic non-small-cell lung cancer. J ClinOncol 1999;17 (5):12-18.

31. Fossella F, Pereira JR, von Pawel J et al. Randomized, multinational, phase III study of docetaxel plus platinum combinations versus vinorelbine plus cisplatin for advanced non-small-cell lung cancer: The TAX 326 study group. J ClinOncol 2003;21 (5):3016-24.

32. Niho S, Nagao K, Nishiwaki Y et al. Randomized multicenter phase III trial of irinotecan (CPT-11) and cisplatin (CDDP) versus CDDP and vindesine (VDS) in patients with advanced non-small cell lung cancer (NSCLC). Proc Am SocClinOncol 1999;18 (4):492a.

33. Negoro S, Masuda N, Takada Y et al. Randomised phase III trial of irinotecan combined with cisplatin for advanced non-small-cell lung cancer. Br J Cancer 2003;88 (6):335-41.

34. Ohe Y, Ohashi Y, Kubota K et al. Randomized phase III study of cisplatin plus irinotecan versus carboplatin plus paclitaxel, cisplatin plus gemcitabine, and cisplatin plus vinorelbine for advanced non-small-cell lung cancer: Four-arm cooperative study in Japan. Ann Oncol 2007;18 (2):317-23.

35. Rosell R, Taron M, BarnadasA et al. Nucleotide excision repair pathways involved in cisplatin resistance in non-small-cell lung cancer. Cancer Control 2003;10 (3):297-305.

36. Rosell R, Cobo M, Isla D et al. ERCC1 mRNA-based randomized phase III trial of docetaxel doublets with cisplatin or gemcitabine in stage IV non-small cell lung cancer patients. J ClinOncol 2005;23(16 suppl):7002.

37. Rosell R, Danenberg KD, Alberola V et al. Ribonucleotidereductase messenger RNA expression and survival in gemcitabine/cisplatintreated advanced non-small cell lung cancer patients. Clin Cancer Res 2004;10 (8):1318-25.

38. Rosell R, Gatzemeier U, Betticher DC et al. Phase III randomised trial comparing paclitaxel/carboplatin with paclitaxel/cisplatin in patients with advanced nonsmall-cell lung cancer: A cooperative multinational trial. Ann Oncol 2002;13 (2):1539-49.

39. Hotta K, Matsuo K, Ueoka H et al. Meta-analysis of randomized clinical trials comparing cisplatin to carboplatin in patients with advanced nonsmall-cell lung cancer. J ClinOncol 2004;22 (5):3852-59.

40. Ardizzoni A, Tiseo M, Boni L et al. CISCA (cisplatin vs. 
carboplatin) meta-analysis: An individual patient data meta-analysis comparing cisplatin versus carboplatinbased chemotherapy in first-line treatment of advanced non-small cell lung cancer (NSCLC). J ClinOncol 2006;24(18 suppl):7011.

41. D'Addario G, Pintilie M, Leighl NB et al. Platinumbased versus nonplatinum-based chemotherapy in advanced non-small-cell lung cancer: A meta-analysis of the published literature. J ClinOncol 2005;23 (1):2926-36.

42. Giaccone G, Herbst RS, Manegold C et al. Gefitinib in combination with gemcitabine and cisplatin in advanced non-small-cell lung cancer: A phase III trial-INTACT 1. J ClinOncol 2004;22(3):777-84.

43. Herbst RS, Giaccone G, Schiller JH et al. Gefitinib in combination with paclitaxel and carboplatin in advanced non-small-cell lung cancer: A phase III trial-INTACT 2. J ClinOncol 2004;22 (5):785-94.

44. Herbst RS, Prager D, Hermann R et al. TRIBUTE: A phase III trial of erlotinib hydrochloride (OSI-774) combined with carboplatin and paclitaxel chemotherapy in advanced non-small-cell lung cancer. J ClinOncol 2005;23 (2):5892-99.

45. Kelly K, Hanna N, Rosenberg A et al. A multi-centered phase I/II study of cetuximab in combination with paclitaxel and carboplatin in untreated patients with stage IV non-small cell lung cancer. ProcSoc Am ClinOncol 2003;22 (1):644.

46. Rosell R, Daniel C, Ramlau R et al. Randomized phase II study of cetuximab in combination with cisplatin (C) and vinorelbine (V) vs. CV alone in the first-line treatment of patients (pts) with epidermal growth factor receptor (EGFR)-expressing advanced non-smallcell lung cancer (NSCLC). Proc Am SocClinOncol 2004;23 (4):618.

47. Sandler A, Gray R, Perry MC et al. Paclitaxelcarboplatin alone or with bevacizumab for non-smallcell lung cancer. N Engl J Med 2006;355 (1):2542-50.

48. Smith IE, O'Brien ME, Talbot DC et al. Duration of chemotherapy in advanced non-small-cell lung cancer: A randomized trial of three versus six courses of mitomycin, vinblastine, and cisplatin. J ClinOncol 2001;19 (2):1336-43.

49. Socinski MA, Schell MJ, Peterman A et al. Phase III trial comparing a defined duration of therapy versus continuous therapy followed by second-line therapy in advanced-stage IIIB/IV non-small-cell lung cancer. J ClinOncol 2002;20 (7):1335-43.

50. Westeel V, Quoix E, Moro-Sibilot D et al. Randomized study of maintenance vinorelbine in responders with advanced non-small-cell lung cancer. J Natl Cancer Inst 2005;97 (6):499-506.

51. Von Plessen C, Bergman B, Andresen O et al. Palliative chemotherapy beyond three courses conveys no survival or consistent quality-of-life benefits in advanced nonsmall-cell lung cancer. Br J Cancer 2006;95 (2): 966-73.

Source of Support: Nil; Conflict of Interest: None

Submitted: 22-03-2019; Accepted: 21-04-2019; Published online: 25-06-2019 